\title{
Tecnura
}

\section{Decision Support Systems (DSS) Applied to the Formulation of Agricultural Public Policies}

\section{Sistemas de soporte de decisiones (SSD) aplicados a la formulación de políticas públicas agrarias}

\author{
Juan Manuel Sánchez Céspedes ${ }^{\circledR}{ }^{\circledR}$, Juan Pablo Rodríguez Miranda ${ }^{2}$, \\ Olga Lucia Ramos Sandoval ${ }^{3}$
}

Fecha de recepción: 22 de Diciembre de 2019

Fecha de aceptación: 13 de Agosto de 2020

Cómo citar: Sánchez-Céspedes., J.M. Rodríguez-Miranda., J.P. Ramos-Sandoval ., y O.L. (2020). Decision Support Systems (DSS) Applied to the Formulation of Agricultural Public Policies. Tecnura, 24(66), 95-108. https:// doi.org/10.14483/22487638.15768

\begin{abstract}
Objective: The process of formulating agricultural public policies is complex due to the large number of variables involved in it. However, there is a methodology that helps the process: the development of decision support systems (DSS). This article shows the results of reviewing the developments made on implementing DSS on the formulating agricultural public policies.
\end{abstract}

Methodology: A bibliographic review was carried out in various scientific databases by looking for implementations of SSD on the process of formulating agricultural policies. After finding out the SSD systems developed, qualitative and descriptive analyzes of the systems were carried out.

Results: Thirty DSS systems applied to the formulation of agricultural policies were found, and the majority is focused on the agricultural production process and its relationship with the environment.

Conclusions: When developing potential agricultural policies, there is a fundamental need to generate
DSS that determine possible future behavior of stakeholders. These DSS also need to be adjusted to the characteristics of the countries located in the tropical zone.

Financing: Universidad Distrital Francisco José de Caldas, Universidad Militar Nueva Granada.

Keywords: Decision Support Systems, DSS, Public Policy, Policymaking, Agriculture, Agricultural Sector.

\section{Resumen}

Objetivo: El proceso de formulación de políticas públicas agrarias es altamente complejo por la gran cantidad de variables que intervienen en el proceso. Por eso, el desarrollo de sistemas de soporte de decisiones (SSD) ayudan a mejorar dicho proceso. El artículo revisa los desarrollos que se han realizado con respecto al tema.

Metodología: Se realizó una revisión bibliográfica en varias bases de datos científicas, buscando desarrollos de sistemas SSD aplicados al proceso de formulación de políticas agrarias. Al determinar cuáles

1 Magíster en Administración, Especialista en Teleinformática, Ingeniero Electrónico. Profesor Asociado, Universidad Distrital Francisco José de Caldas, Facultad de Ingeniería. Bogotá D.C., Colombia. Contacto: jmsanchezc@udistrital.edu.co

2 Doctor en Ingeniería, Magíster en Ingeniería Ambiental, Magíster en Gestión y Evaluación Ambiental, Ingeniero Sanitario y Ambiental. Profesor Titular, Universidad Distrital Francisco José de Caldas, Facultad de Medio Ambiente y Recursos Naturales, Bogotá D.C., Colombia. Contacto: jprodriguezm@udistrital.edu.co

3 Doctor en Ingeniería, Magister en Teleinformatica, Esp. en Instrumentación Electrónica, Ingeniera Electrónica. Profesor Asociado, Universidad Militar Nueva Granada, Facultad Ingeniería, Bogotá D.C., Colombia. Contacto: olga.ramos@unimilitar.edu.co 
sistemas SSD se han desarrollado, se procedió a realizar un análisis cualitativo y también descriptivo de los sistemas.

Resultados: Se encontraron 30 sistemas SSD aplicados a la formulación de políticas agrarias, donde la mayoría están enfocados al proceso de producción agrícola y su relación con el medio ambiente.

Conclusiones: Al formular posibles políticas agrarias, es muy necesario generar sistemas SSD que predigan el futuro comportamiento de las partes involucradas. Adicionalmente, estos sistemas deben ser ajustados para que tengan en cuenta las características de los países localizados en la zona tropical.

Financiamiento: Universidad Distrital Francisco José de Caldas, Universidad Militar Nueva Granada.

Palabras clave: Sistemas de Soporte de Decisiones, SDD, Política Pública, Formulación de Políticas, Agricultura, Sector Agrario.

\section{INTRODUCTION}

The process of formulating agricultural policies is complex by definition. This complexity starts because of the many variables the process entaiIs: public policy makers should use their region's political, economic, social, cultural, and environmental needs as inputs for the process (Cárdenas \& Vallejo, 2016; Morgan, Marsden, Miele, \& Morley, 2010; Rodríguez Espinosa, Ramírez Gómez, \& Restrepo-Betancur, 2016; Sánchez, Rincón, \& Lugo, 2013). Additionally, they must aim for the development of these policies to promote sustainable development, such as that proposed by the United Nations Development Program (PNUD, 2019). Therefore, the results of the policies must generate economic growth, poverty reduction, food security, negative environmental impact reduction, decent work, inequality reduction, production, and responsible consumption (Boza, 2013; Firbank, Les G; Petit Sandrine, Smart Simon; Blain, Alasdair; Fuller, 2008; Guanziroli, 2014; Suárez, 2015; Temprano, 2013; Vargas, Boada, Araca, Vargas, \& Vargas, 2016). All these elements make it a highly complex process which Olson called "Organized Anarchy." He explains that the complexity is directly related to the integration of many agents and actions that intervene the process (Vergara Varela, 2016).

Furthermore, it is worth highlighting that the limited rationality of the human being restricts the decision-making process during the formulation of public policies. Helbert Simon, Nobel Prize in Economics, explains that limited rationality is the decision-making process done in a partially irrational way due to cognitive, information, or time restrictions during the process (Capra, 2014).

All these factors cause unexpected results from public policies generated, which go against sustainable development and the objectives set by the policy when formulated. For example, in Colombia the implementation of agrarian policies has triggered an increase in production and also generated an increase in social inequality by concentrating land ownership in a few people (Baudasse \& Calderón, 2009; Gómez, 2016; Morales, Morales, \& Rizo, 2017; Ospina, 2017; Soto, 2003).

On the other hand, systems that help make the decision-making process easier have been developed in recent decades. They are called Decision Support Systems (DSS) and are computational solutions that can be used to support complex decision making and problem solving. The traditional design of a DSS system is made up of three components. The first component consists of robust database management capabilities. The second component consists of powerful modeling functions that are accessed by a model management system. Finally, the third component consists of the system having a user friendly graphical interface (Shim et al., 2002).

Therefore, DSS propose an alternative to reduce the uncertainty that possible results can generate when implementing agricultural policies. For this reason, there have been several researches around the world that have developed DSS for the formulation of agricultural public policies in order to foresee possible future results depending on the 
implementation of the policies formulated. This article reviews different DSS applied to the formulation of agricultural public policies throughout the world during recent years.

\section{METHODOLOGY}

The applied methodology is descriptive in nature with a qualitative approach. First, a search for publications related to the topic was first performed on scientific databases such as IEEE, SpringerLink, Science Direct, Scopus, and Web of Science. In these databases, the following words were used when searching: "Decision Support Systems," "Public policy," "Policymaking," "Farming," and "Agriculture". Once the results were obtained, a manual review was carried out to determine the relationship between the documents and the objective of the investigations, and to analyze the relevance and the use of each DSS during the formulating of agricultural policies. Thirty DSS applied to agricultural policies were found.

\section{RESULTS}

Table 1 presents the summary of the DSS that were found after the search and debugging process. The first column shows the year of creation of the system (i.e. each system's first version) since several of the oldest systems have been continuously updated. The second column is the name the creators called each system. In some cases there was no name assigned to the DSS; in those cases, the indicative "Not Registered" was placed.

The third column briefly describes the application of the DSS when formulating agrarian public policy, although a deeper explanation of each system is better explained below Table 1. The fourth column refers to the country for which each system was design and implemented.

EPIC (Erosion/Productivity Impact Calculator) is a system that determines the relationship between soil erosion and soil productivity in the United States. It continuously simulates the processes associated with erosion. EPIC is made up of components based on hydrology, climate simulation, erosion-sedimentation, nutrient cycling, plant growth, tillage, and soil temperature. It also uses calculations to assess the economic cost of erosion, and to determine optimal management strategies (Sharpley \& Williams, 1990).

CropSyst is a system written in $\mathrm{C}++$, and its first version was developed in 1992. This System is used to analyze the effect of crop management on productivity and the environment. It simulates the use of water in the soil, the level of nitrogen in the soil plant, the growth of crops and roots, the production of dry matter, yield, the production and decomposition of residues, and the erosion. Management options include crop selection, crop rotation, irrigation, nitrogen fertilization, tillage operations, and residue management (Stöckle, Nelson, \& Kemanian, 2019).

LUPAS (Land Use Planning and Analysis System) was designed as a DSS for strategic land use planning. The system includes Crop Simulation Models, Expert Systems, SIG, and Multiple Objective Linear Programming (MGLP) models for land evaluation and optimization. LUPAS has three main parts: first, land assessment, which includes assessing resource availability, land suitability, and yield estimation; second, construction of scenarios based on policy opinions; and third, the optimization of land use (Roetter et al., 2005).

AgClimate is a web-based weather forecasting and information system. AgClimate was implemented in a Linux environment with specific applications and Perl modules installed. Dynamic tools were developed using the PHP web programming language that interacts with FLASH movies and MySQL databases. The system has two main components: the front-end interface and a set of dynamic tools. The main navigation menu includes weather forecast tools and management options for crops, forestry, pastures, and livestock. It also includes a section on climate and "El Niño" phenomenon with background information. The tools section contains two applications that allow the user to examine the weather forecast for individual counties based on the ENSO phase and assess the yield potentials for certain crops (Fraisse et al., 2006). 
Table 1. Decision Support Systems in Formulating Agricultural Public Policies.

\begin{tabular}{|c|c|c|c|}
\hline Year & Name SSD & Application & Countries \\
\hline 1990 & EPIC & $\begin{array}{l}\text { To determine the relationship between soil erosion and soil } \\
\text { productivity. }\end{array}$ & United States \\
\hline 1992 & CropSyst & $\begin{array}{l}\text { Analysis of the effect of crop management on productivity } \\
\text { and environment. }\end{array}$ & United States \\
\hline 2005 & LUPAS & Land use planning. & Netherlands, Philippines, Germany \\
\hline 2006 & AgClimate & Weather information and forecast. & United States \\
\hline 2007 & APSIM & Simulates biophysical processes in agricultural systems. & Australia, New Zealand \\
\hline 2008 & LWIDSS & Land use and impact on water. & Canada \\
\hline 2008 & PERFECT & $\begin{array}{l}\text { Predict runoff (water flow over land), soil erosion, and crop } \\
\text { production. }\end{array}$ & Australia, Canada, China \\
\hline 2009 & Water for Tomorrow & Land use and water resources management. & China \\
\hline 2009 & EDSS & Water resources management. & China \\
\hline 2009 & MedAction & Hypothetical analysis of various policy alternatives. & Netherlands \\
\hline 2009 & DeSurvey & $\begin{array}{l}\text { To support policy decisions related to sustainable agricultu- } \\
\text { re, water resource management, and land degradation. }\end{array}$ & Netherlands, United Kingdom \\
\hline 2009 & IWM & Water resources management. & Australia, Bangladesh \\
\hline 2009 & AQUATOOL & Water resources management. & Spain \\
\hline 2009 & Not Registered & Land use and sustainable management. & Vietnam \\
\hline 2010 & MAFIC-DSS & Selection of alternative crops. & Greece \\
\hline 2010 & LUMOCAP & Land use. & $\begin{array}{l}\text { Netherlands, Poland, Belgium, } \\
\text { Spain, Italy, Denmark }\end{array}$ \\
\hline 2010 & MPMAS & Water use. & Germany \\
\hline 2010 & MicroLEIS & $\begin{array}{l}\text { Multifunctional evaluation of the biophysical quality of the } \\
\text { soil. }\end{array}$ & Spain \\
\hline 2011 & FARMERS & $\begin{array}{l}\text { Manure management as fertilizer and reduction of soil } \\
\text { contamination. }\end{array}$ & Denmark \\
\hline 2011 & IPAD DSS & Assessment of world agricultural production. & United States \\
\hline 2012 & Not Registered & Soil and water conservation within an agricultural basin. & United States \\
\hline 2013 & PAU_TRACPWR & Crop machinery management. & India \\
\hline 2013 & Not Registered & Protection of vineyards against the plague called "Oídio." & France \\
\hline 2015 & ARIES & Simulation and evaluation of human impact on nature. & Peru, Denmark, United Kingdom \\
\hline 2015 & VULPES & Environmental risk assessment of pesticides. & Italy \\
\hline 2015 & ALL_WATER_gw & Groundwater management. & Tunisia, United States, Germany. \\
\hline 2016 & SmartScape ${ }^{\mathrm{TM}}$ & Strategic planning of crop change. & United States, Denmark, Iran \\
\hline 2017 & DSSAT & Evaluation and application of crop models. & United States \\
\hline 2018 & DESTISOL & Assessment of the ecosystems planned for the soils. & France \\
\hline 2019 & NitroShed & $\begin{array}{l}\text { Simulates farmers' decision-making process and how } \\
\text { policies might affect adoption rates of best management } \\
\text { practices. }\end{array}$ & United States \\
\hline
\end{tabular}

Source: Authors.

The APSIM (Agricultural Production Systems Simulator) is a system that simulates biophysical processes in agricultural systems, and specifically determines the possible economic and ecological results of management practices against climate risk. It also analyzes food security, and adaptation to climate change. APSIM is structured around plant, soil, and management modules. The creators, Queensland University (Australia), started developing it in 2007 (APSIM, 2019).

The LWIDSS (Land and Water Integration Decision Support System) simulates land use scenarios 
characterized by different assumptions about management practices. The results are presented in the form of SIG spatial layers. These can be incorporated into other components, such as non-point source pollutant models to assess the impact of soil quality on water. Land use scenarios are integrated with watershed hydrology models to develop flow, sediment, and nutrient performance standards in streams to protect aquatic biodiversity (Wong et al., 2008).

PERFECT (Productivity Erosion and Runoff Functions to Evaluate Conservation Techniques) is a system that was designed to predict runoff (water flow over the land), erosion, and crop production to determine the sequences of planting, harvesting, and management of residues under different tillage practices. This model has been used widely in the agricultural areas of Australia, China, and India, among others (Li, Tullberg, Freebairn, McLaughlin, \& Li, 2008).

The "Water for Tomorrow" DSS is designed to assist policymakers in making decisions about land use and water resource management, taking into account human use, preservation, and restoration of the ecosystem. Users can locate the watershed of interest, view summary data on that watershed, view and compare model results, and generate reports (Eckman, West, Barford, \& Raber, 2009).

They developed a web-based regional agricultural industry structure optimization tool in China, using AJAX (Asynchronous JavaScript and XML) technology and a suite of decision support tools for agricultural policymakers. The system provides a configuration method that allows applying sensitivity analysis, data use, and analysis results of comparative advantage, and a component that can solve the linear programming model and its double problem by the simplex method (Huang \& Zhu, 2009).

The Integrated Environmental Decision Support System (EDSS) was designed to help policymakers and other stakeholders gain a clearer understanding of key factors in water resource management. The system is made using MATLAB and a geographic information system (SIG). The model considers the social, economic, ecological, environmental system of water, and water resources as its interrelated subsystems, and integrates them into an organic whole to analyze. The system provides a visual simulation environment, and analysis and management capabilities of water resources for different scenarios (Leng \& Haimid, 2009).

The MedAction Policy Support System (PSS) aims to support policymakers in arid and semi-arid regions in understanding the impacts of autonomous developments within a region, such as demographic and economic growth, or change climate. The system allows hypothetical analyzes of various policy alternatives; policy indicators can measure impact such as agricultural sector gains, forest area, water use and availability, land degradation, and changes in land use. The system is made up of several sub-modules, which are integrated into a single model that simulates regional developments up to thirty years in the future (H. Van Delden, 2009).

The DeSurvey Integrated Assessment Model (DeSurvey IAM) is a policy formulation support system. The system aims to support political decisions related to sustainable agriculture, water resource management, and land degradation. The system contains twenty models that include climate, hydrology, water management, erosion, salinization, vegetation growth, land use, macroeconomics, crop choice, and irrigation, among others, and they work with different spatial and temporal resolutions. Depending on the issue at hand and the data available, a region-specific application can be configured to contain a proper combination of built-in models (H. Van Delden, Kirkby, \& Hahn, 2009).

Researchers from the Institute of Water Modeling (IWM) developed a Water Resources DSS that uses mathematical models to simulate and predict likely impacts in sectors such as agriculture. The DSS has been designed to be an educational tool for non-technical users and stakeholders. Thus, users can obtain information about the risks associated with climate change and also the effectiveness of different adaptation options (Zaman, Rahman, \& Khan, 2009).

AQUATOOL is a DSS for basins and water resource planning and management (Andreu, Pérez, Paredes, \& Solera, 2009). The system consists of 
several modules. The SIMGES module is a general model for the Simulation of Watershed Management, in which there are elements of regulation, storage, collection, transport, and consumption. The GESCAL module was developed to determine the quality of the water. The OPTIGES module defines the monthly distribution of water. The SIMRISK module is for watershed management and risk measurement. The EVALHID module (Evaluation of water resources) is used to develop Precipitation-Runoff Models (Andreu Álvarez, 2019).

Researchers from Vietnam developed a decision support system for agricultural land use planning and sustainable management. The system is made up of the following components: the optimal problem-solving component helps the decision maker to solve the optimal problem; the expert opinion component helps the decision maker to establish the necessary requirements and expert data in order to combine it with expert opinions using the Delphi method; the reporting and Implementation Component helps to report the final option selected on the planning map. The system was developed using Microsoft Visual Studio together with Maplnfo MapXtreme and was designed based on three main objectives: economic efficiency, land suitability, and sustainable environment (Huy, 2009).

The MAFIC-DSS (Major Field Crops Decision Support System) is web-based and supports farmers in the selection procedure of appropriate alternative crops. The system provides the necessary information and supports the farmer throughout the growing period. The system has seven modules: The user profile module stores information for each farmer; the SIG module contains the necessary spatial information and stores data such as land use, cadastral information, soil characteristics, and climatic characteristics; the agricultural policy module contains all the national and EU agricultural policies and directives necessary for each crop of interest; the market profile module maintains the market information and the cultivation cost for each product, which refers mainly to market prices, national and international demand for each product, prices and specifications of fertilizers and pesticides, means of transportation, and energy costs; the interaction module is a chat-like application enriched with image upload facilities that allows farmers to send inquiries to experts using text and photos of their fields; and finally, the crop module, which consists of two submodules. The first sub-module contains different knowledge bases related to the main crops, such as soil and climate cultivation requirements and cultivation techniques, including needs for fertilization and irrigation. The second sub-module is a system for the chemical and organic management of pests and diseases (Antonopoulou, Karetsos, Maliappis, \& Sideridis, 2010).

The LUMOCAP System (dynamic land use change modeling for CAP impact assessment on the rural landscape) aims to assess how different political scenarios will affect land and landscape use in the 27 member States of the European Union. Due to the inherent complexity of land use change processes, agricultural policies at European level have their effect not only on the evolution of the agricultural sector, but also on the regional ecological coherence and socio-economic dynamics of rural areas. The system allows the following up of relationships between EU policies, agricultural economy, land suitability, and land use dynamics through simulation (Hedwig Van Delden et al., 2010).

MPMAS (Mathematical Programming-based Multi-Agent Systems) is a system developed by the Hohenheim University. It was implemented using $\mathrm{C}++$, and its user interface offers two modes. The first mode is the single agent mode, which simulates a decision problem for a single agent. The second mode is the complete agent, where decision making and actions of all agents like production, investment and consumption decisions, agent-agent interactions, and all relevant biophysical processes are simulated generally for several years. The system was used to predict the behavior of farmers in the use of water when building a dam (Berger, Schilling, Troost, \& Latynskiy, 2010).

The decision support system MicroLEIS (Mediterranean Land Evaluation Information System) was designed for the multifunctional evaluation of the biophysical quality of the soil, using the 
characteristics of the soil such as place, climate, and cultivation as input data, and it is particularly applied to the peculiarities of the Mediterranean region. This DSS was designed to have a toolkit that integrates databases, statistical models, expert systems, neural networks, web and GIS applications, and other information technologies (De la Rosa \& Anaya-Romero, 2010).

Fertilizing by Application and Reuse of Manure Environmental Risk Software (FARMERS) is a decision-making system for the safe and sustainable management of livestock manure as a fertilizer in order to control and limit the accumulation of metals in the soil and to reduce metal bio-transference from the floor to other compartments. The system was developed based on a multi-compartment model for evaluating environmental risks. The tool was implemented in Visual $\mathrm{C}++$ and is structured in a database (MS Access $\left.{ }^{\circledR}\right)$ where all the required data is stored and the risk assessment model, a GIS module for the visualization of the scenario, and the results are obtained. The decision support system allows you to choose between three estimation options depending on the needs, which provide information to both farmers and policymakers. The first option is useful for evaluating the suitability of the current management practices of the different farms, and the others provide information on the measures that can be taken to carry out a fertilization plan without exceeding the risk to human health (Río, Franco-Uría, Abad, \& Roca, 2011).

The IPAD DSS (International Production Assessment Division decision support system) was developed by NASA and aims to assess world agricultural production. The system takes global data, model input sources, and analysis tools to estimate crop production. The multiple data and results of the model are the basis for processing, analysing and visualization techniques that lead to an evidence convergence approach to the monthly estimates of production of specific products in each country (Van Leeuwen et al., 2011).

A decision support system for soil and water conservation within an agricultural basin was designed and used to generate alternative decision support scenarios to facilitate integrated watershed management concepts in an interactive and holistic way (Lal, 2012).

A decision support system called PAU_TRACPWR for crop machinery management in India was developed. Detailed data information on the production parameters of the main crops, such as tractor prices, crop values, workloads, and the level of adoption of various agricultural technologies were used for designing the system (Bector \& Singh Surendra, 2013).

A DSS for the protection of vineyards against the plague called "Oídio" ("blanquilla" or "cenicilla") because this plague must be treated before any symptoms appear. The system simulates the entire life cycle of the pathogen, including sexual and asexual reproduction modes, while estimating the area of the diseased leaf. The system is modeled after mathematical equations and expert knowledge (Garin, Houlès, \& Jallas, 2013).

A Decision Support System to identify land strategically located for the agrarian reform that developed in South Africa was developed in 2014. The system was built from geographic information systems (GIS), Earth Observation (EO) data, and multi-criteria decision making (MCDM). An index to identify the land was created, expert workshops to determine the criteria for land identification were conducted, and the analytical hierarchy process (AHP) was used to weight the criteria (Musakwa, Makoni, Kangethe, \& Segooa, 2014).

ARIES is a dynamic modeling platform that uses artificial intelligence techniques to simulate and evaluate the impact of human intervention on nature. The system integrates a set of process- and agent-based models to identify the changes in flows of ecosystem services as a response to changes in land use and weather, as well as the impact and scope of future land use scenarios in the region (Francesconi, Pérez Miñana, Willcock, Villa, \& Quintero, 2015).

VULPES ("Vulnerability to Pesticide") is a system based on GIS, client-server type designed for groundwater. The system aims to transfer scientific knowledge for evaluating environmental risks from 
pesticides, which allows to apply consolidated models and methodologies used in standardized scenarios for regulatory purposes and to identify vulnerable areas to pesticides. It is a system intended to help those responsible for public policies investigate sensitive areas to specific substances and propose limitations of use or mitigation measures (Di Guardo \& Finizio, 2015).

ALL_WATER_gw was developed for groundwater management within the framework of the WEAP-MODFLOW DSS. The system takes into account water demand, minimization of water cost, maximum reduction, and compliance with water salinity restrictions. The system uses a multi-objective genetic algorithm (MOGA) and PARETO optimization approaches to handle the formulated problem (Nouiri, Yitayew, Maßmann, \& Tarhouni, 2015).

The SmartScapeTM DSS is a system with an interactive web-based environment for strategic crop change planning, which allows users to create and evaluate a crop change scenario. This system has three main components: A terrain selection panel; a scenario panel that allows stakeholders to make a crop change and run multiple environmental models; and a comparison scenario panel that allows users to compare the outcome of crop change scenarios in various ecosystem services using various visual analyzes and highlight the tradeoffs between multiple ecosystem services (Tayyebi, Arsanjani, Tayyebi, Omrani, \& Moghadam, 2016).

The DSSAT is a comprehensive system that helps the evaluation and application of crop models for a variety of agricultural and environmental uses, such as yield predictions and water use (Salazar et al., 2012). This serves as support for agricultural planning and regional policy. The DSS contains various crop and soil simulation models, as well as climate, soil and crop databases, and evaluation programs (Wolfe \& Richard, 2017).

The DESTISOL DSS is based on an integrative approach that links the indicators of soil characteristics: quality (i.e. physicochemical and biological characteristics, fertility, and contamination), functions, and ecosystem services. With this linking, the system also semi-quantitatively evaluates the ecosystem services that are provided by the soil as food production, air quality, flood mitigation, or climate regulation (Anne et al., 2018).

NitroShed is a system that was developed using agent-based modeling in Python. The system simulates the decision-making process of farmers in the Mississippi Basin and the Mexico Gulf. Additionally, it presents a simulation of how policies might affect adoption rates of best management practices affecting also the repercussions that farming activities may have on the soil. For example, the implementation of best practices could reduce the contamination produced by nutrients released by the farms located in the surrounding hydrographic basins. The system helps policymakers determine the most effective action plan to increase the adoption of best management practices by farmers (Zeman \& Rodríguez, 2019).

After reviewing the functions for which the DSS have been developed, it is worth noting that the main objective is focused on determining land use, managing water resources in agriculture, optimizing productivity, influencing the climate, and reduce the negative environmental impact of economic activity. In summary, all DSS are focused on issues related to the agricultural production process and its relationship with the environment. Only two DSS have a slightly different approach: the MPMAS developed in 2010, and the NitroShed developed in 2019. Both seek to predict the future behavior of farmers on different scenarios, proposing different possible public policies in order to establish which would be most advisable. These two DSS were developed using Artificial Intelligence (AI) and agentbased models.

Figure 1 shows a curve showing the historical development of DSS applied to the formulation of agricultural public policies.

As observed in Figure 1, 2009 is the year when the designing and implementation of DSS applied to the formulating of agrarian policies grew. Although the developments did not stop after this year, most of the systems were already existing and updated to enhanced versions in order to better adjust to the needs of their stakeholders. Therefore, the 


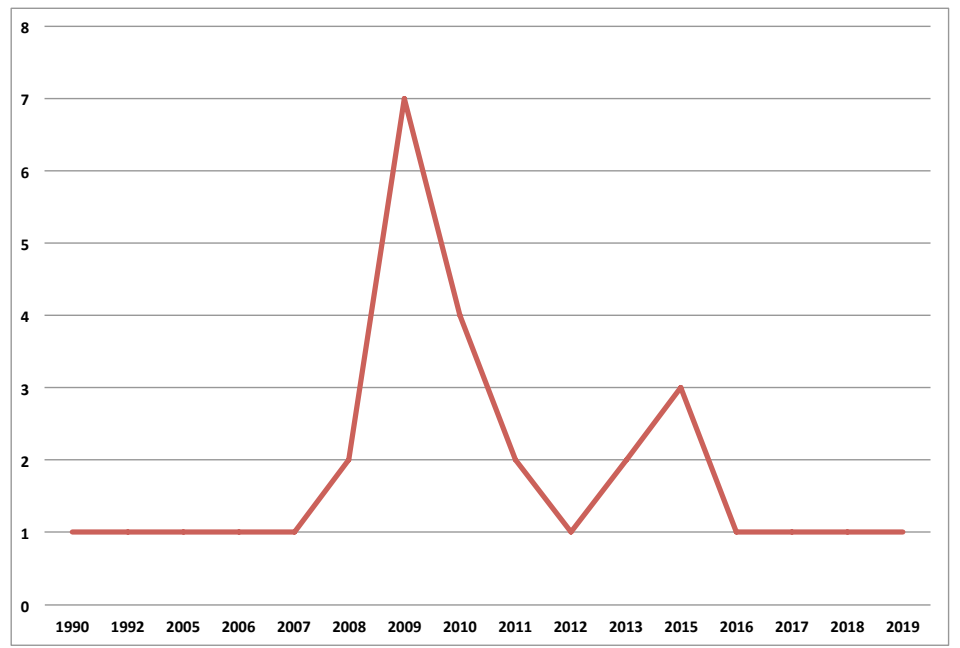

Figure 1. Historical Development of DSS applied to Formulation of Agrarian Policies.

Source: Authors.

development of DSS applied to formulating of the agricultural policies has shown progress during the last 10 years.

Figure 2 presents the percentage distribution of the DSS regarding the countries of origin. Several DSS were developed in collaboration with researchers from different countries, as can be seen in Table 1.

As seen in Figure 2, the country that has developed most DSS is the United States of America, followed by Spain, Netherlands, China, Germany, Australia, France, Italy, and Canada. It is worth noticing that most of the countries that developed these systems belong to Europe or North America, and all of them are considered developed countries, except for China; but China is the second largest economy in the world. It is also interesting that all these countries do not belong to the tropical zone. Therefore, there is an interest in developed countries and those with greater economies for improving their agrarian policy formulation processes using tools such as DSS. Moreover, there is a need to develop these types of tools for countries located in the tropical zone, so that the characteristics of this region may be taken into consideration.

Currently one of the greatest concerns for developed and developing countries is the formulation of policies that promote sustainable development. Such is the concern that the United Nations promulgated the 17 sustainable development goals in 2015 (United Nations Development Program, 2019), and the policies that promote these goals become more relevant, and the agricultural sector becomes one of the fundamental axes for achieving these goals. The sustainable development goals related to agricultural public policies and the development of SSD systems are compared below.

The first related goal is the end of poverty: $17.2 \%$ of the population of rural areas are living in poverty, which is more than three times the rate in urban areas (UN, 2020). The agricultural sector is the most relevant in rural areas, so promoting policies to generate decent employment in the agricultural sector will help reduce poverty rates. Nevertheless, DSS for agricultural policy formulation usually do not take this aspect into consideration.

Another goal is zero hunger. According to the World Food Program, currently 135 million people in the world suffer from severe hunger, which is also a consequence of the economic impact generated by the Covid-19 pandemic (World Food Program, 2020). Thus, the need to reform the world agri-food system (UN, 2019b). Among the DSS analyzed, not one was found that considers this characteristic, so 


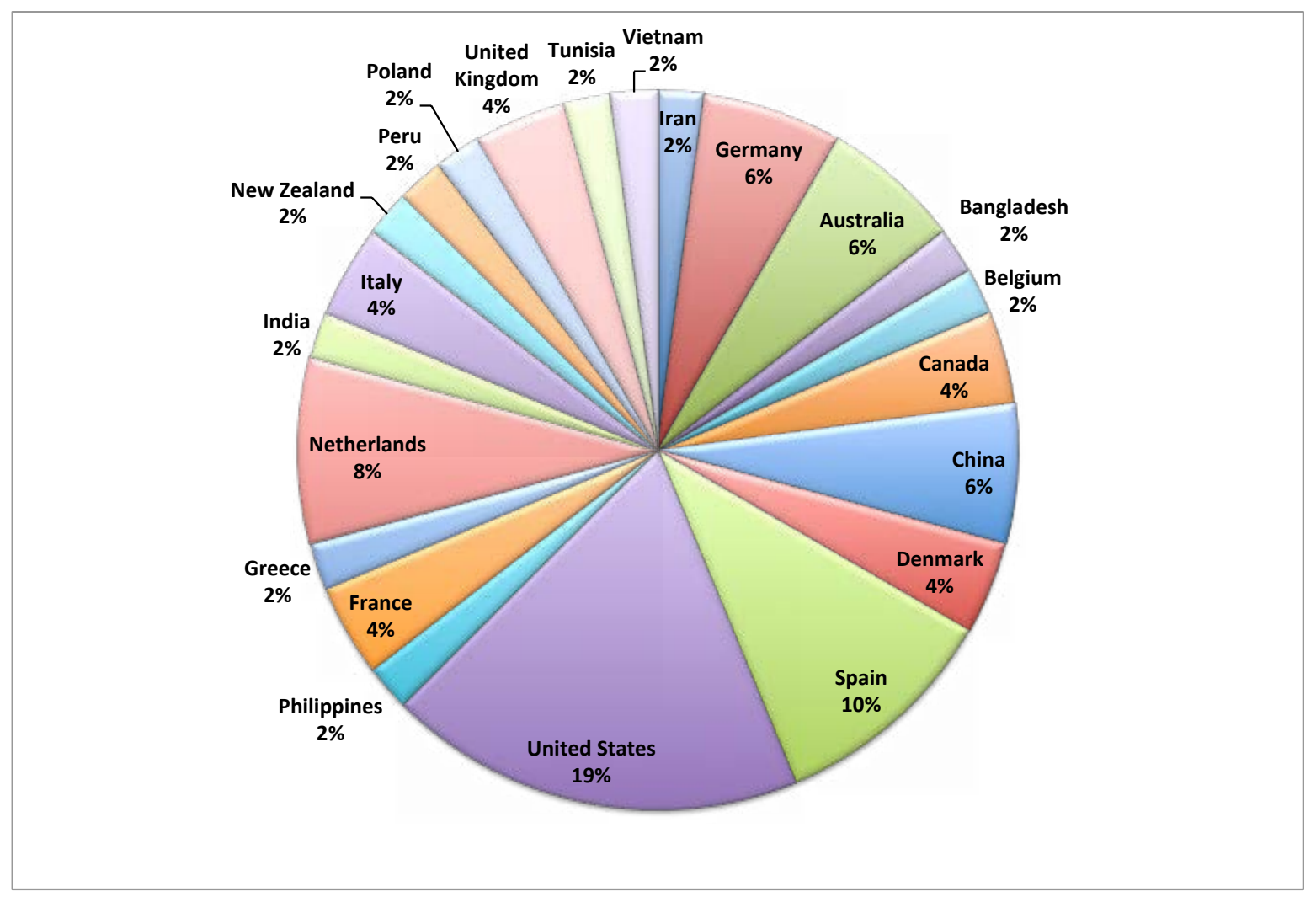

Figure 2. Percentage distribution of DSS for the formulating of agricultural policies.

Source: Authors.

there is still a need to include this variable when developing DSS.

Another related goal is clean water and sanitation. It has been established that billions of people do not have access to drinking water, especially those located in rural areas (UN, 2015). Several systems were developed to improve decision-making in the management of water resources in the agricultural sector, they would be useful for the development of policies that promote the fulfillment of this sustainable objective.

The goal of decent work and economic growth is closely related to the goal of ending poverty. The development of agricultural policies that promote the economic growth of the sector are useful in this case, and so will be the DSS that contribute to the formulating process in this area. Most of the systems developed so far seek to improve productivity and the resource management, which align with the fulfillment of this objective.

The objective of responsible production and consumption is the closest to the agricultural sector. This objective consists of decoupling economic growth from environmental degradation, increasing resource efficiency, and promoting sustainable lifestyles (UN, 2017). Therefore, DSS that seek to develop sustainable agriculture and help reduce the negative environmental impact will be consistent with the achievement of the objective.

Lastly, climate action is one of the objectives worth mentioning. This objective raises the need to create strategies to mitigate the effects generated by climate change (UN, 2019a). Therefore, DSS that include climate as one of their variables will help formulate better agricultural policies (Sánchez C., Rodriguez M., \& Montenegro M., 2020). 
Tools like DSS can be very useful to develop agricultural policies that contribute to the fulfillment of the sustainable development objectives. However, these systems need to take into account characteristics such as poverty in rural areas and food security. These changes would make the systems more robust, so they contribute more comprehensively to meeting goals such as those mentioned above. These characteristics are suggested as lines of future research in this area.

\section{CONCLUSIONS}

Decision support systems (DSS) developed so far aim mainly to improve agricultural production processes and reduce the negative impact of agricultural production on the environment; besides, they can help meet the sustainable development goals, but it is necessary to implement new features to these systems so that they take into account variables like poverty and food security.

Also, two DSS have been identified to predict the future behavior of farmers with different public policies and use an Artificial Intelligence tool called agent-based models.

The interest of the most economically developed countries in improving their agricultural policy formulation processes using tools such as DSS is evident.

\section{FINANCING}

Universidad Distrital Francisco José de Caldas. Universidad Militar Nueva Granada.

\section{REFERENCES}

Andreu Álvarez, J. (2019). AquaTool - AquaTool. Retrieved December 19, 2019, from https://aquatool.webs. upv.es/aqt/aquatool/

Andreu, J., Pérez, M. A., Paredes, J., \& Solera, A. (2009). Participatory analysis of the Jucar-Vinalopo (Spain) water conflict using a decision support system. 18th World IMACS Congress and MODSIMO9 International Congress on Modelling and Simulation:
Interfacing Modelling and Simulation with Mathematical and Computational Sciences, Proceedings, (July), 3230-3236.

Anne, B., Geoffroy, S., Cherel, J., Warot, G., Marie, S., Noël, C. J., ... Christophe, S. (2018). Towards an operational methodology to optimize ecosystem services provided by urban soils. Landscape and Urban Planning, 176(April), 1-9. https://doi.org/10.1016/j. landurbplan.2018.03.019

Antonopoulou, E., Karetsos, S. T., Maliappis, M., \& Sideridis, A. B. (2010). Web and mobile technologies in a prototype DSS for major field crops. Computers and Electronics in Agriculture, 70(2), 292-301. https:// doi.org/10.1016/j.compag.2009.07.024

APSIM. (2019). What is APSIM?-APSIM. Retrieved December 18, 2019, from https://www.apsim.info/ apsim-model/

Baudasse, T., \& Calderón, C. (2009). Integración comercial del sector agrícola y desigualdad económica en los países en vías de desarrollo. investigación económica, 68(269), 37-72. https://doi.org/10.22201/ fe.01851667p.2009.269.16603

Bector, V., \& Singh Surendra, G. P. K. (2013). Predicting Tractor Power Requirements Using Decision Support System - A Tool for Farm Machinery Management. Agricultural Engineering Today, 37(1), 7-14.

Berger, T., Schilling, C., Troost, C., \& Latynskiy, E. (2010). Knowledge-brokering with agent-based models: Some experiences from irrigation-related research in Chile. Modelling for Environment's Sake: Proceedings of the 5th Biennial Conference of the International Environmental Modelling and Software Society, iEMSs 2010, 1(December 2015), 791-800.

Boza, S. (2013). evolución del sector agrícola-ecológico: el caso de Andalucía, España. Cuadernos de Desarrollo Rural, 10, 291-310. Retrieved December 20, 2019, from http:// web.a.ebscohost.com/ehost/pdfviewer/pdfviewer?vid $=1 \&$ sid=a8d4348e-3680-428d-a77d-48de2a8405ce\%40sessionmgr4010

Capra, C. M. (2014). Racionalidad limitada y procesos de decisión. (September).

Cárdenas, J. I., \& Vallejo, L. E. (2016). Agricultura y desarrollo rural en Colombia 2011-2013: una aproximación. Apuntes Del Cenes, 35(62), 87-123. https:// doi.org/10.19053/22565779.4411 
De la Rosa, D., \& Anaya-Romero, M. (2010). MicroLEIS DSS: For planning agro-ecological soil use and management systems. En Decision Support Systems in Agriculture, Food and the Environment: Trends, Applications and Advances. https://doi.org/10.4018/9781-61520-881-4.ch016

Di Guardo, A., \& Finizio, A. (2015). A client-server software for the identification of groundwater vulnerability to pesticides at regional level. Science of the Total Environment, 530-531, 247-256. https://doi. org/10.1016/j.scitotenv.2015.05.112

Eckman, B., West, P. C., Barford, C., \& Raber, G. (2009). Intuitive simulation, querying, and visualization for river basin policy and management. IBM Journal of Research and Development, 53(3). https://doi. org/10.1147/JRD.2009.5429020

Firbank, Les G; Petit Sandrine, Smart Simon; Blain, Alasdair; Fuller, R. J. (2008). Assessing the impacts of agricultural intensification on biodiversity: a British perspective. Trans. R. Soc. B, 363(1492), 777-787. https://doi.org/10.1098/rstb.2007.2183

Fraisse, C. W., Breuer, N. E., Zierden, D., Bellow, J. G., Paz, J., Cabrera, V. E., ... O'Brien, J. J. (2006). AgClimate: A climate forecast information system for agricultural risk management in the southeastern USA. Computers and Electronics in Agriculture, 53(1), 1327. https://doi.org/10.1016/j.compag.2006.03.002

Francesconi, W., Pérez Miñana, E., Willcock, S. P., ViIla, F., \& Quintero, M. (2015). Linking ecosystem services to food security in a changing planet: assessing Peruvian Amazon deforestation using the Artificial Intelligence for Ecosystem Services (ARIES) framework. ASABE 1st Climate Change Symposium: Adaptation and Mitigation Proceedings of the 3-5 May 2015 Conference. Chicago Illinois, USA.

Garin, G., Houlès, V., \& Jallas, E. (2013). Assembly of a model for grapevine powdery mildew in a decision support system and search for evaluation criteria. Precision agriculture '13, 525-531. https://doi. org/10.3920/978-90-8686-778-3

Gómez, P. P. (2016). Evaluación de la política pública de reforma agraria en Colombia (1991 - 2010): Estudios de caso en seis municipios del país (Universidad Nacional de Colombia Facultad). Retrieved
December 22, 2019, from http://www.bdigital.unal. edu.co/53481/

Guanziroli, C. E. (2014). Evolución de la Política Agrícola Brasileña: 1980-2010. Mundo Agrário, 15(29), 1-33. Retrieved December 23, 2019, from http:// www.mundoagrario.unlp.edu.ar/

Huang, X., \& Zhu, Y. (2009). Study on web-based tool for regional agriculture industry structure optimization using Ajax. IFIP Advances in Information and Communication Technology, 295, 1543-1550. https:// doi.org/10.1007/978-1-4419-0213-9_3

Huy, M. Q. (2009). Building a Decision Support System for Agricultural Land Use Planning and Sustainable Management at the District Level in Vietnam. Elements.

Lal, R. (2012). Climate Change and Soil Degradation Mitigation by Sustainable Management of SoiIs and Other Natural Resources. Agricultural Research, 1(3), 199-212. https://doi.org/10.1007/ s40003-012-0031-9

Leng, Z. X., \& Haimid, Y. (2009). Environmental decision support system development for soil salinization in the arid area oasis. 2008 International Seminar on Business and Information Management, ISBIM 2008, 1, 449-452. https://doi.org/10.1109/ISBIM.2008.242 Li, Y. X., Tullberg, J. N., Freebairn, D. M., McLaughlin, N. B., \& Li, H. W. (2008). Effects of tillage and traffic on crop production in dryland farming systems: I. Evaluation of PERFECT soil-crop simulation model. Soil and Tillage Research, 100(1-2), 15-24. https:// doi.org/10.1016/j.still.2008.04.004

Morales, S. L., Morales, M. R., \& Rizo, R. (2017). Metodología para Procesos de Inteligencia de Negocios con mejoras en la extracción y transformación de fuentes de Datos. Revista Publicando, 4(11), 107-119. Retrieved December 27, 2019, from http://rmlconsultores. com/revista/index.php/crv/article/view/553/pdf_364

Morgan, S. L., Marsden, T., Miele, M., \& Morley, A. (2010). Agricultural multifunctionality and farmers' entrepreneurial skills: A study of Tuscan and Welsh farmers. Journal of Rural Studies, 26(2), 116-129. https://doi.org/10.1016/j.jrurstud.2009.09.002

Musakwa, W., Makoni, E. N., Kangethe, M., \& Segooa, L. (2014). Developing a decision support system to 
identify strategically located land for land reform in South Africa. International Archives of the Photogrammetry, Remote Sensing and Spatial Information Sciences-ISPRS Archives, 40(2), 197-203. https:// doi.org/10.5194/isprsarchives-XL-2-197-2014

Nouiri, I., Yitayew, M., Maßmann, J., \& Tarhouni, J. (2015). Multi-objective Optimization Tool for Integrated Groundwater Management. Water Resources Management, 29(14), 5353-5375. https://doi. org/10.1007/s11269-015-1122-8

Ospina, D. M. (2017). Reivindicando al campesinado en Colombia: Análisis de las fallas de redistribución y de reconocimiento en la implementación de las Política Agrarias de los Siglos XX-XXI, y en la Política Pública de Víctimas y Restitución de Tierras.

Programa de las Naciones Unidas para el Desarrollo (PNUD). (2019). Objetivos de Desarrollo Sostenible | PNUD. Retrieved October 15, 2019, from https:// www.undp.org/content/undp/es/home/sustainable-development-goals.html

Río, M., Franco-Uría, A., Abad, E., \& Roca, E. (2011). A risk-based decision tool for the management of organic waste in agriculture and farming activities (FARMERS). Journal of Hazardous Materials, 185(2-3), 792-800. https://doi.org/10.1016/j. jhazmat.2010.09.090

Rodríguez Espinosa, H., Ramírez Gómez, C. J., \& Restrepo-Betancur, L. F. (2016). Análisis Comparativo De La Dinámica De Desarrollo Agrícola En Suramérica En El Período 1980-2010. Luna Azul, (42), 15-29. https://doi.org/10.17151/luaz.2016.42.3 https://doi. org/10.17151/luaz.2016.42.3

Roetter, R. P., Hoanh, C. T., Laborte, A. G., Van Keulen, H., Van Ittersum, M. K., Dreiser, C., ... Van Laar, H. H. (2005). Integration of Systems Network (SysNet) tools for regional land use scenario analysis in Asia. Environmental Modelling and Software, 20(3), 291307. https://doi.org/10.1016/j.envsoft.2004.01.001

Salazar, M. R., Hook, J. E., Garcia y Garcia, A., Paz, J. O., Chaves, B., \& Hoogenboom, G. (2012). Estimating irrigation water use for maize in the Southeastern USA: A modeling approach. Agricultural Water Management, 107, 104-111. https://doi.org/10.1016/j. agwat.2012.01.015
Sánchez, V., Rincón, M. A. R., \& Lugo, L. J. (2013). Imaginarios Rurales $Y$ Agropecuarios $Y$ Políticas Agrarias En El Departamento Del Caquetá, Colombia. Ingenierías \& Amazonia, 6(1), 37-46.

Sánchez C., J. M., Rodriguez M., J. P., \& Montenegro M., C. E. (2020). La relevancia de la variabilidad climática en la formulación de políticas públicas agrarias en los países tropicales. Revista ESPACIOS, 41(8), 11.

Sharpley, A. N., \& Williams, J. R. (1990). EPIC: The erosion-productivity impact calculator. U.S. Department of Agriculture Technical Bulletin, (1768), 235. Retrieved December 29, 2019, from http://agris.fao.org/ agris-search/search.do? recordID=US9403696

Shim, J. P., Warkentin, M., Courtney, J. F., Power, D. J., Sharda, R., \& Carlsson, C. (2002). Past, present, and future of decision support technology. Decision Support Systems, 33(2), 111-126. https://doi. org/10.1016/S0167-9236(01)00139-7

Soto, C. (2003). La agricultura comercial de los distritos de riego en México y su impacto en el desarrollo agrícola. Investigaciones Geográficas, Boletín del Instituto de Geografía, UNAM, (50), 173-195.

Stöckle, C. O., Nelson, R., \& Kemanian, A. (2019). CS_ Suite-CropSyst. Retrieved December 18, 2019, from http://modeling.bsyse.wsu.edu/CS_Suite_4/CropSyst/ index.html

Suárez, J. (2015). Producción integrada de alimentos y energía a escala local en Cuba: bases para un desarrollo sostenible. Pastos y Forrajes, 38(1), 3-10.

Tayyebi, A., Arsanjani, J. J., Tayyebi, A. H., Omrani, H., \& Moghadam, H. S. (2016). Group-based crop change planning: Application of SmartScape ${ }^{\mathrm{TM}}$ spatial decision support system for resolving conflicts. Ecological Modelling, 333, 92-100. https://doi.org/10.1016/j. ecolmodel.2016.04.018

Temprano, A. G. (2013). Política agraria común y la de cohesión frente a la Estrategia Europa 2020. Problemas del Desarrollo, 44(173), 105-132. Retrieved December 27, 2019, from https://www.scopus.com/ inward/record.uri?eid=2-s2.0-84875383047 \&partnerID=40\&md5=e9b3b6b63fcc3937b1753af$07 \mathrm{~d} 6 \mathrm{e} 8896$

UN. (2015). Water and sanitation-Sustainable Development. Retrieved October 16, 2020, from 
United Nations website: https://www.un.org/ sustainabledevelopment/es/water-and-sanitation/

UN. (2017). Sustainable consumption and productionSustainable Development. Retrieved October 16, 2020, from Sustainable Development Goals website: https://www.un.org/sustainabledevelopment/es/ sustainable-consumption-production/

UN. (2019a). Climate change-Sustainable Development. Retrieved October 16, 2020, from Sustainable Development Goals website: https://www.un.org/ sustainabledevelopment/es/climate-change-2/

UN. (2019b). Hunger and food security-Sustainable Development. 2019. Retrieved from https://www. un.org/sustainabledevelopment/es/hunger/

UN. (2020). Poverty-Sustainable Development. Retrieved October 16, 2020, from Sustainable Development Goals website: https://www.un.org/ sustainabledevelopment/es/poverty/

United Nations Development Program (UNDP). (2019). Sustainable Development Goals | PNUD. Retrieved June 24, 2019, from https://www.undp.org/content/ undp/es/home/sustainable-development-goals.html

Van Delden, H. (2009). Integration of socio-economic and bio-physical models to support sustainable development. 18th World IMACS Congress and MODSIM09 International Congress on Modelling and Simulation: Interfacing Modelling and Simulation with Mathematical and Computational Sciences, Proceedings, (July), 2457-2463.

Van Delden, H., Kirkby, M. J., \& Hahn, B. M. (2009). Towards a modelling framework for integrated assessment in arid and semi-arid regions. 18th World IMACS Congress and MODSIM09 International Congress on Modelling and Simulation: Interfacing Modelling and Simulation with Mathematical and Computational Sciences, Proceedings, (July), 3563-3569.

Van Delden, Hedwig, Stuczynski, T., Ciaian, P., Paracchini, M. L., Hurkens, J., Lopatka, A., ... Vanhout, R. (2010). Integrated assessment of agricultural policies with dynamic land use change modelling. Ecological Modelling, 221(18), 2153-2166. https://doi.org/10.1016/j.ecolmodel.2010.03.023

Van Leeuwen, W., Hutchinson, C., Drake, S., Doorn, B., Kaupp, V., Haithcoat, T., ... Tralli, D. (2011). Benchmarking enhancements to a decision support system for global crop production assessments. Expert Systems with Applications, 38(7), 8054-8065. https:// doi.org/10.1016/j.eswa.2010.12.145

Vargas, D., Boada, M., Araca, L., Vargas, W., \& Vargas, R. (2016). Sostenibilidad de modos ancestrales de producción agrícola en el Perú: ¿conservar o sustituir? Mundo Agrario, 17(35), 10. Retrieved December 29, 2019, from http://www.mundoagrario.unlp. edu.ar/article/view/MAe023

Vergara Varela, R. (2016). Modelos de Toma de Decisión: Anarquía-Isomorfismos-Psicoanálisis.

Wolfe, M. L., \& Richard, T. L. (2017). 21St Century Engineering for on-Farm Food-Energy-Water Systems. Current Opinion in Chemical Engineering, 18 (November), 69-76. https://doi.org/10.1016/j. coche.2017.10.005

Wong, I., Fong, P., Booty, W. G., Nielsen, C., Benoy, G., \& Swayne, D. A. (2008). The land and water integration decision support system. 14th Americas Conference on Information Systems, AMCIS 2008, 1, 516-522.

World Food Programme. (2020). 2020-Global Report on Food Crises | World Food Programme. Retrieved October 16, 2020, from https://www.wfp.org/ publications/2020-global-report-food-crises

Zaman, A. M., Rahman, S. M. M., \& Khan, M. R. (2009). Development of a DSS for Integrated Water Resources Management in Bangladesh. 18th World IMACS Congress and MODSIMO9 International Congress on Modelling and Simulation: Interfacing Modelling and Simulation with Mathematical and Computational Sciences, Proceedings, (July), 2756-2762.

Zeman, K. R., \& Rodríguez, L. F. (2019). Quantifying farmer decision-making in an agent-based model. 2019 ASABE Annual International Meeting.

\section{(c) (1) () ()}

Tecnura • p-ISSN: 0123-921X • e-ISSN: 2248-7638 • Vol. 24 No. 66 • Octubre - Diciembre de $2020 \bullet$ pp. 95-108 [ 108 ] 